\title{
Model Pilihan Pembelajaran, Inquiry Atau Expository?
}

\author{
Jumaisa \\ Ilmu Pendidikan Sosial, Fakultas Tarbiyah, IAIN Parepare \\ jumaisa@iainpare.ac.id
}

\begin{abstract}
There is no one the best learnings model compared to the other model. A learning model can be effective when it has reached the established goal. This research aims at providing the choice of learning models , whether inquiry or expository. The type of this research was literature by synthesize the literature data and previous studies. In the inquiry model, students are mentally and physically involved in solving the problem provided by the teachers, whereas the expository model, it emphasizes more on the way of speaking of teachers in delivering the material of subject
\end{abstract}

Keywords: expository, inquiry, learning.

\begin{abstract}
Abstrak
Tidak ada satu model pembelajaran yang dianggap lebih baik dibandingkan dengan model pembelajaran yang lain. Suatu model pembelajaran bisa dilihat dari efektif saat sudah mencapai tujuan pembelajaran yang telah ditentukan. Penelitian ini bertujuan untuk menyediakan model pilihan pembelajaran, apakah inquiry atau expository. Jenis penelitian ini adalah kepustakaan dengan mengkaji data-data kepustakaan dan penelitian terdahulu. Dalam model pembelajaran inkuiri, peserta didik terlibat secara mental dan fisik untuk memecahkan suatu permasalahan yang diberikan guru, sedangkan model pembelajaran ekspositori lebih menekankan pada proses bertutur guru dalam menyampaikan materi pelajaran.
\end{abstract}

Kata Kunci: ekspositori, inkuiri, ekspositori, pembelajaran.

\section{PENDAHULUAN}

Pembelajaran yang efektif adalah pembelajaran yang menyediakan kesempatan belajar sendiri atau melakukan aktivitas sendiri. Proses pembelajaran yang dilakukan di dalam kelas merupakan aktivitas mentransformasikan pengetahuan, sikap, dan ketrampilan (Martinis Yamin, 2007: 75). Aktivitas merupakan prinsip atau asas yang sangat penting dalam interaksi belajar mengajar (Sardiman, 2006: 96).

Aktivitas belajar dapat terwujud apabila peserta didik terlibat belajar secara aktif. Martinis Yamin (2007: 82) mendefinisikan belajar aktif sebagai usaha manusia untuk membangun pengetahuan dalam dirinya. Pembelajaran akan menghasilkan suatu perubahan dan peningkatan kemampuan, pengetahuan dan ketrampilan pada diri peserta didik. Peserta didik mampu menggali kemampuannya dengan rasa ingin tahunya sehingga interaksi yang terjadi akan menjadi pengalaman dan keinginan untuk mengetahui sesuatu yang baru. Aktivitas belajar yang dilakukan oleh setiap peserta didik dalam kelas selalu berbeda. Hal ini dipengaruhi oleh penggunaan metode dan pendekatan pembelajaran serta orientasi aktivitas (Djamarah, 2003: 81). Ketidaksamaan aktivitas peserta didik menimbulkan perkembangan tingkat aktivitas peserta didik dari yang rendah menuju aktivitas peserta didik yang lebih tinggi.

Saat pembelajaran belangsung peserta didik mampu memberikan umpan balik terhadap guru. Sardiman (2006: 100) menyatakan bahwa aktivitas belajar merupakan aktivitas yang bersifat fisik maupun mental. Dalam kegiatan belajar keduanya saling berkaitan. Oemar Hamalik (2009: 179) menyatakan bahwa aktivitas belajar merupakan kegiatan yang dilakukan oleh peserta didik dalam kegiatan pembelajaran. Berdasarkan hal ini, dapat disimpulkan bahwa aktivitas belajar merupakan kegiatan atau tindakan baik fisik maupun mental yang dilakukan oleh individu untuk membangun 
pengetahuan dan keterampilan dalam diri dalam kegiatan pembelajaran. Aktivitas belajar akan menjadikan pembelajaran yang efektif. Pendidik tidak hanya menyampaikan pengetahuan dan keterampilan saja. Namun, pendidik harus mampu membawa peserta didik untuk aktif dalam belajar. Oleh karena itu, penelitian ini menguraikan model pembelajaran inquiry dan expository yang akan menungkapkan perbedaan keunggulan dan kelemahan.

\section{METODE}

Dalam memecahkan suatu masalah atau permasalahan yang dihadapi, metode penelitian mempunyai peranan penting dalam penelitian ilmiah, disini diperlukan metode yang sesuai dengan masalah yang akan diteliti sehingga memperoleh hasil yang diharapkan.

Dalam penelitian ini. jenis penelitian kepustakaan yang digunakan. Metode dokumentasi dilakukan untuk memperoleh datadata terkait penelitian. Setelah data diperoleh, teknik analisis data dilakukan menggunakan analisis konten. Kajian mengenai evaluasi program dianalisis.

\section{HASIL DAN PEMBAHASAN \\ Model Pembelajaran Inkuiri}

Istilah inkuiri berasal dari Bahasa Inggris, yaitu inquiry yang berarti pertanyaan atau penyelidikan. Pembelajaran inkuiri adalah suatu rangkaian kegiatan belajar yang melibatkan secara maksimal seluruh kemampuan peserta didik untuk mencari dan menyelidiki secara sistematis, kritis, logis, analitis, sehingga siswa dapat merumuskan sendiri penemuannya dengan penuh percaya diri (Trianto 2007: 135). Inkuiri merupakan model pembelajaran yang membimbing peserta didik untuk memperoleh dan mendapatkan informasi serta mencari jawaban atau memecahkan masalah terhadap pertanyaan yang dirumuskan.

Secara umum inkuiri merupakan proses yang bervariasi dan meliputi kegiatan-kegiatan mengobservasi, merumuskan pertanyaan yang relevan, mengevaluasi buku dan sumber informasi lain secara kritis, merencanakan penyelidikan atau investigasi, mereview apa yang telah diketahui, melaksanakan percobaan atau eksperimen dengan menggunakan alat untuk memperoleh data, menganalisis dan menginterpretasi data, serta membuat prediksi dan mengkomunikasikan hasilnya (Ibrahim, 2007: 2).

Sejalan dengan hal tersebut, Kardi (2003: 3) mendefinisikan "inkuiri adalah model pembelajaran yang dirancang untuk membimbing siswa bagaimana meneliti masalah dan pertanyaan berdasarkan fakta". Model inkuiri menekankan pada proses mencari dan menemukan, peran peserta didik, dalam model ini adalah mencari dan menemukan sendiri pemecahan masalah dalam suatu materi pelajaran sedangkan guru sebagai fasilitator dan pembimbing peserta didik untuk belajar.

Selanjutnya Cleaf (dalam Putrayasa, 2009: 2) menyatakan bahwa "inkuiri adalah salah satu strategi yang digunakan dalam kelas yang berorientasi proses, inkuiri merupakan sebuah strategi pengajaran yang berpusat pada peserta didik, yang mendorong siswa untuk menyelidiki masalah dan menemukan informasi”.

Lebih lanjut Sagala (2006: 197) menyatakan "ada lima tahapan yang ditempuh dalam melaksanakan model inkuiri yaitu: (1) perumusan masalah yang dipecahkan siswa, (2) menetapkan jawaban sementara (hipotesis), (3) siswa mencari informasi, data fakta yang diperlukan untuk menjawab permasalahan, (4) menarik kesimpulan jawaban atau generalisasi, dan (5) mengaplikasikan kesimpulan atau generalisasi dalam situasi baru". Wahab (2009: 92) mengatakan bahwa "penting untuk dipahami oleh guru bahwa inkuiri yang didasarkan pada pemecahan masalah yang ilmiah merupakan salah satu dari sekian banyak cara untuk mengetahui bahwa sesuatu itu benar. Selain itu guru juga harus mengurangi intervensi terhadap kegiatan peserta didik dalam memecahkan masalah". Gulo (dalam Susanto, 2014: 184) menyebutkan beberapa peran guru dalam pembelajaran inkuiri sebagai berikut.

1. Motivator; guru memberikan rangsangan supaya siswa aktif dan bergairah dalam berpikir.

2. Fasilitator; guru menunjukan jalan keluar jika ada hambatan dalam proses berpikir siswa.

3. Penanya; guru menyadarkan peserta didik dari kekeliruan yang mereka 
perbuat dan memberi keyakinan pada diri sendiri.

4. Administrator; guru bertanggung jawab terhadap seluruh kegiatan didalam kelas.

5. Pengarah; guru memimpin arus kegiatan berpikir peserta didik pada tujuan yang diharapkan.

6. Manager; guru mengolah sumber belajar, waktu dan organisasi kelas.

7. Rewarder; guru memberi penghargaan pada prestasi yang dicapai dalam rangka peningkatan semangat heuristik pada peserta didik.

Dari beberapa pendapat di atas dapat dismpulkan bahwa model inkuiri adalah model pembelajaran yang menekankan kepada peserta didik untuk lebih aktif dalam pembelajaran, dimana peserta didik dapat menemukan atau meneliti masalah berdasarkan fakta untuk memperoleh data, sedangkan guru hanya sebagai fasilitator dan pembimbing peserta didik dalam belajar.

\section{Ciri-ciri Model Pembelajaran Inkuiri}

Ciri-ciri merupakan sesuatu yang khas yang membedakan suatu hal dengan hal lainnya. Sanjaya (dalam Susanto, 2014: 164) menyebutkan ciri utama dalam pembelajaran inkuiri sebagai berikut.

1) Menekankan pada aktivitas peserta didik secara maksimal untuk mencari dan menemukan.

2) Seluruh aktivitas yang dilakukan peserta didik diarahkan untuk mencari dan menemukan jawaban sendiri dari sesuatu yang dipertanyakan.

3) Bertujuan untuk mengembangkan kemampuan berpikir secara sistematis dan kritis atau mengembangkan kemampuan intelektual sebagai bagian dari proses mental.

Pada penelitian ini, tingkatan model inkuiri yang digunakan terbatas pada inkuiri terbimbing (guided inquiry). Inkuiri terbimbing adalah inkuiri yang banyak dicampuri oleh guru. Guru banyak mengarahkan dan memberikan petunjuk baik lewat prosedur yang lengkap dan pertanyaan-pertanyaan pengarahan selama proses inkuiri. Inkuiri terbimbing (guided inkuiry) merupakan kegiatan inkuiri dimana masalah dikemukakan oleh guru atau bersumber dari buku teks kemudian peserta didik bekerja untuk menemukan jawaban terhadap permasalahan tersebut dibawah bimbingan intensif guru (Amri dan Ahmadi, 2010: 89). Kusmana (2010: 49) mengemukakan bahwa model pembelajaran inkuiri digunakan apabila dalam kegiatan pembelajaran guru menyediakan bimbingan atau petunjuk yang cukup luas kepada siswa. Sebagaian besar perencanaanya dibuat oleh guru. Dalam inkuiri terbimbing kegiatan belajar harus dikelola dengan baik oleh guru dan output pembelajaran sudah dapat diprediksi sejak awal.

Jadi dapat disimpulkan bahwa dalam model pembelajaran inkuiri terbimbing (guided inkuiry), guru banyak terlibat dalam hal membuat perencanaan dan pertanyaan-pertanyaan pengarahan selama proses inkuiri sehingga peserta didik tidak begitu bebas dalam hal mengembangkan gagasan dan idenya. Melalui model pembelajaran inkuiri terbimbing, peserta didik yang berperan sebagai subjek pembelajaran dilatih bekerja seperti ilmuan. Dengan begitu, penggunaan model pembelajaran inkuiri terbimbing diharapkan mampu mempengaruhi kemampuan berpikir kreatif peserta didik kearah yang positif.

Beberapa karakteristik inkuiri terbimbing yang harus diperhatikan yakni sebagai berikut;

1) Mengembangkan kemampuan berpikir peserta didik melalui observasi spesifik hingga mampu membuat inferensi atau generalisasi.

2) Sasarannya adalah mempelajari proses pengamatan kejadian atau objek dan menyususn generalisasi yang sesuai.

3) Guru mengontrol bagian tertentu dari pembelajaran, misalnya kejadian, data, materi dan berperan sebagai pemimpin kelas.

4) Setiap peserta didik berusaha membangun pola yang bermakna berdasarkan hasil observasi di dalam kelas.

5) Kelas diharapkan berfungsi sebagai laboratorium pembelajaran.

6) Biasanya sejumlah generalisasi akan diperoleh dari peserta didik. 
7) Guru memotivasi peserta didik untuk mengkomunikasikan hasil dari generalisasinya sehingga dapat dimanfaatkan oleh seluruh peserta didik dalam kelas.

\section{Prinsip-prinsip Pembelajaran Inkuiri}

Penggunaan model pembelajaran inkuri memiliki beberapa prinsip, antara lain:

- Berorientasi pada pengembangan intelektual. Tujuan utama dari pembelajaran inkuiri adalah pengembangan kemampuan berpikir dan berorientasi pada proses belajar. Keberhasilan pembelajaran ini terlihat pada aktivitas peserta didik untuk mencari dan menemukan sesuatu yang merupakan gagasan pasti.

- Prinsip interaksi. Proses pembelajaran meruapakan interaksi antar peserta didik dengan pendidik yang mana pendidik berperan sebagai pengatur lingkungan dan pengatur interaksi belajar, pendidik mengarahkan peserta didik untuk mengembangkan kemampuan berpikir peserta didik.

- Prinsip bertanya. Guru juga berperan sebagai penanya karena kemampuan peserta didik untuk bertanya pada dasarnya sudah merupakan bagian dari proses berpikir.

- Prinsip belajar untuk berpikir. Belajar merupakan proses berpikir yakni proses mengembangkan potensi seluruh otak secara maksimal.

- Prinsip keterbukaan. Belajar adalah suatu proses mencoba berbagai kemungkinan. Untuk itu peserta didik hendaknya diberikan kebebasan untuk mencoba sesuatu sesuai dengan perkembangan kemampuan logika dan nalarnya. Tugas guru adalah menyediakan ruang untuk mengembangkan hipotesis dan secara terbuka membuktikan kebenaran hipotesis yang diajukan.

\section{Langkah-langkah Pembelajaran Inkuiri}

Sanjaya (2007: 199) menjabarkan langkah-langkah pembelajaran inkuiri sebagai berikut. Pertama adalah orientasi. Pada langkah ini guru mengondisikan agar peserta didik siap melaksanakan proses pembelajaran dengan cara merangsang dan mengajak peserta didik untuk berpikir memecahkan masalah. Langkah orientasi merupakan langkah yang sangat penting, karena keberhasilan pembelajaran inkuiri sangat tergantung pada kemauan peserta didik untuk beraktivitas menggunakan kemampuannya dalam memecahkan masalah. Beberapa hal yang dilaksanakan pada tahap orientasi adalah sebagai berikut:

a. Menjelaskan topik, tujuan, dan hasil belajar yang diharapkan dapat dicapai oleh peserta didik.

b. Menjelaskan pokok-pokok kegiatan yang harus dilakukan oleh peserta didik untuk mencapai tujuan. Pada tahap ini dijelaskan langkah-langkah inkuiri serta tujuan setiap langkah, mulai dari langkah merumuskan masalah sampai dengan merumuskan kesimpulan.

c. Menjelaskan pentingnya topik dan kegiatan belajar. Hal ini dilakukan dalam rangka memberikan motivasi kepada peserta didik.

Kedua adalah merumuskan masalah. Pada langkah ini guru membawa peserta didik pada suatu persoalan yang mengandung teka-teki. Persoalan yang disajikan adalah persoalan yang menantang siswa untuk berpikir memecahkan teka-teki itu. Proses berpikir dan mencari jawaban teka-teki itulah yang sangat penting dalam strategi inkuiri, oleh karena itu melalui proses tersebut peserta didik akan memperoleh pengalaman yang sangat berharga sebagai upaya mengembangkan mental melalui proses berpikir. Beberapa hal yang perlu diperhatikan dalam merumuskan masalah adalah sebagai berikut;

a. Masalah hendaknya dirumuskan sendiri oleh peserta didik. peserta didik akan memiliki motivasi belajar yang tinggi manakala dilibatkan dalam merumuskan masalah yang hendak dikaji.

b. Masalah yang dikaji adalah masalah yang mengandung teka-teki dan jawabannya pasti.

c. Konsep-konsep dalam masalah adalah konsep-konsep yang sudah diketahui terlebih dahulu oleh peserta didik. Artinya, sebelum masalah itu dikaji 
lebih jauh melalui melalui proses inkuiri, guru perlu yakin terlebih dahulu bahwa peserta didik sudah memiliki pemahaman tentang konsep-konsep yang ada dalam rumusan masalah.

Ketiga adalah mengajukan hipotesis. Kemampuan atau potensi individu untuk berpikir pada dasarnya sudah dimiliki sejak individu itu lahir. Potensi berpikir tersebut dimulai dari kemampuan setiap individu untuk menebak atau mengira-ngira (berhipotesis) dari suatu permasalahan. Salah satu cara yang dapat dilakukan guru untuk mengembangkan kemampuan berhipotesis pada setiap anak adalah dengan mengajukan berbagai pertanyaan yang dapat mendorong peserta didik untuk dapat merumuskan jawaban sementara atau dapat merumuskan berbagai perkiraan kemungkinan jawaban dari suatu permasalahan yang dikaji. Keempat adalah mengumpulkan data dan menguji hipotesis.

Dalam pembelajaran inkuiri, mengumpulkan data merupakan proses mental yang sangat penting dalam pengembangan intelektual. Proses pengumpulan data bukan hanya memerlukan motivasi yang kuat dalam belajar, akan tetapi juga membutuhkan ketekunan dan kemampuan menggunakan potensi berpikirnya. Oleh sebab itu, tugas dan peran guru dalam tahapan ini adalah mengajukan pertanyaan-pertanyaan yang dapat mendorong peserta didik untuk berpikir mencari informasi yang dibutuhkan. Menguji hipotesis adalah proses menentukan jawaban yang dianggap diterima sesuai dengan data atau informasi yang diperoleh berdasarkan pengumpulan data. Yang terpenting dalam menguji hipotesis adalah mencari tingkat keyakinan peserta didik atas jawaban yang diberikan. Disamping itu, menguji hipotesis juga berarti mengembangkan kemampuan berpikir rasional. Artinya, kebenaran jawaban yang diberikan bukan hanya berdasarkan argumentasi, akan tetapi harus didukung oleh data yang ditemukan dan dapat dipertanggung jawabkan.

Merumuskan kesimpulan adalah proses akhir yang mendeskripsikan temuan yang diperoleh berdasarkan hasil pengujian hipotesis. Kadang banyaknya jawaban yang diperoleh menyebabkan kesimpulan yang diputuskan tidak fokus terhadap masalah yang hendak dipecahkan. Karena itu, untuk mencapai kesimpulan yang akurat guru mampu menunjukkan pada peserta didik data mana yang relevan.

\section{Syarat Inkuiri Dapat Berjalan dengan Baik}

Model inkuiri akan efektif apabila: (1) guru mengharapkan peserta didik dapat menemukan sendiri jawaban dari suatu permasalahan sehingga penguasaan materi bukan tujuan utama karena yang terpenting adalah proses belajar, (2) bahan pelajaran yang akan diajarkan adalah berupa kesimpulan yang perlu pembuktian, (3) proses pembelajaran berangkat dari rasa ingin tahu peserta didik terhadap sesuatu, (4) siswa adalah anak yang memiliki kemauan dan kemampuan berpikir, (5) jumlah peserta didik tidak berlaku banyak agar mudah dikendalikan, dan (6) guru memiliki banyak waktu untuk melakukan pendekatan yang berpusat pada peserta didik.

Roestiyah ( 2008: 77) mengemukakan bahwa untuk mengefesienkan model inkuiri dapat ditimbulkan dengan kegiatan-kegiatan sebagai berikut.

1) Membimbing kegiatan. Guru menyediakan petunjuk yang cukup luas kepada peserta didik dan sebagian besar perencanaannya dibuat oleh guru.

2) Modifikasi ikuiri. Dalam hal ini guru hanya menyediakan masalah-masalah dan menyediakan bahan/alat yang diperlukan untuk memecahkan masalah secara perseorangan maupun kelompok.

3) Kebebasan inkuiri. Guru mengundang peserta didik untuk melibatkan diri dalam kegiatan "kebebasan inkuiri", dari peserta didik dapat mengidentifikasi masalah dan merumuskan macammacam masalah yang akan dpelajari.

4) Inkuiri pendekatan peran. Siswa dilibatkan dalam proses pemecahan masalah, yang cara-caranya serupa dengan cara-cara yang biasanya diikuti oleh para ilmiawan.

5) Mengundang ke dalam inkuiri. Merupakna kegiatan proses belajar yang melibatkan peserta didik dalam tim-tim untuk memecahkan masalah yang 
masing-masing anggota diberi tugas suatu peranan yang berbeda-beda seperti: koodinator tim, penasihat teknis, merekam data, proses penilaian.

6) Teka teki bergambar. Salah satu teknik untuk mengembangkan motivasi, aktifitas dan perhatian peserta didik didalam diskusi kelompok. Gambar peragaan atau situasi yang sesungguhnya dapat digunakan melihat sejauh mana keterpengaruhan ataupun peningkatan cara berpikir kritis dan kreatif peserta didik.

7) Synectics lesson. Pendekatan ini menstimulir bakat bakat kreatif peserta didik. Pada dasarnya "synectics" memusatkan pada keterlibatan peserta didik untuk membuat berbagai macam bentuk kiasan agar dapat membuka intelegensi dan mengembangkan daya kreatifitas. Hal tersebut dapat dilaksanakan karena kiasan dapat membantu dalam melepaskan ikatan struktur mental yang melekat kuat dalam memandang suatu masalah sehingga dapat menunjang timbulnya ide-ide kreatif.

8) Kejelasan nilai-nilai. Perlu diadakan evaluasi lebih lanjut tentang keuntungankeuntungan pendekatan ini, terutama yang menyangkut sikap, nilai-nilai dan pembentukan self-concept siswa.

\section{Kelebihan Model Pembelajaran Inkuiri}

Model pembelajaran inkuiri memiliki keunggulan yang dapat dijabarkan sebagai berikut:

1) Dapat membentuk dan mengembangkan "self-concept" pada diri peserta didik, sehingga dapat mengerti tentang konsep dasar dan ide-ide lebih baik.

2) Membantu dalam menggunakan ingatan dan trasfer pada situasi proses belajar yang baru.

3) Mendorong peserta didik untuk berpikir dan bekerja atas inisiatif sendiri, bersikap obyektif, jujur dan terbuka.

4) Mendorong peserta didik untuk berpikir intuitif dan merumuskan hipotesisnya sendiri.
5) Memberi kepuasan yang bersifat intrinsik.

6) Situasi proses belajar menjadi lebih merangsang.

7) Dapat mengembangkan bakat atau kecakapan individu.

8) Memberi kebebasan peserta didik untuk belajar sendiri.

9) Siswa dapat menghindari dari cara belajar tradisional.

10) Dapat memberikan waktu pada peserta didik secukupnya sehingga mereka dapat mengasimilasi dan mengakomodasi informasi.

Selain keunggulan yang telah dijabarkan, model pembelajaran inkuiri tetap memiliki kekurangan dan kelemahan diantaranya.

1) Jika guru tidak merumuskan teka-teki atau pertanyaan kepada peserta didik dengan baik, untuk memecahkan masalah secara sistematis, maka akan membuat peserta didik bingung dan tidak terarah.

2) Kadang kala guru mengalami kesulitan dalam merencanakan pembelajaran oleh karena terbentur dengan kebiasaan peserta didik dalam belajar.

3) Dalam implementasinya memerlukan waktu yang panjang sehingga guru sering sulit menyesuaikan dengan waktu yang ditentukan.

4) Pada sistem klasikal dengan jumlah peserta didik yang relatif banyak, penggunaan pendekatan ini sukar untuk dikembangkan dengan baik.

5) Selama kriteria keberhasilan belajar ditentukan oleh kemampuan peserta didik menguasai materi, maka pembelajaran ini sulit diimplementasikan oleh guru.

\section{Model Pembelajaran Ekspositori}

Model pembelajaran ekspositori adalah model pembelajaran yang menekankan kepada proses penyampaian materi secara verbal dari seorang guru kepada sekelompok peserta didik dengan maksud agar peserta didik dapat menguasai materi pelajaran secara optimal. Dalam model pembelajaran ini materi pelajaran disampaikan langsung oleh guru. peserta didik tidak dituntut untuk menemukan materi itu. Karena model pembelajaran ekspositori lebih 
menekankan pada proses bertutur guru dalam menyampaikan materi pelajaran, maka model ini sering juga dinamakan model pembelajaran langsung (dirrect intruction). Terdapat beberapa karakteristik model ekspositori diantaranya :

- Model ekspositori dilakukan dengan cara menyampaikan materi pelajaran secara verbal, artinya bertutur secara lisan merupakan alat utama dalam melakukan model ini, oleh karena itu sering mengidentikanya dengan ceramah.

- Biasanya materi pelajaran yang disampaikan adalah materi pelajaran yang sudah jadi, seperti data atau fakta, konsep-konsep tertentu yang harus dihafal sehinga tidak menuntut peserta didik untuk berpikir ulang.

- Tujuan utama pembelajaran dalah penguasaan materi pelajaran itu sendiri. Artinya, setelah proses pembelajaran berakhir peserta didik diharapkan dapat memahaminya dengan benar dengan cara dapat mengungkapkan kembali materi yang sudah diuraikan.

Model pembelajaran ekspositori merupakan bentuk dari pendekatan pembelajaran yang berorientasi kepada guru (teacher centered approach). Dikatakan demikian, sebab dalam model ini guru memegang peran yang sangat dominan. Melalui model ini guru menyampaikan materi pembelajaran secara terstruktur dengan harapan materi pelajaran yang disampaikan itu dapat dikuasai peserta didik dengan baik. Fokus utama model ini adalah kemampuan akademik (academic achievement).

\section{Prinsip Penggunaan Model Pembelajaran Ekspositori}

Tidak ada satu model pembelajaran yang dianggap lebih baik dibandingkan dengan model pembelajaran yang lain. Baik tidaknya suatu model pembelajaran bisa dilihat dari efektif tidaknya model tersebut dalam mencapai tujuan pembelajaran yang telah ditentukan. Dengan demikian, pertimbangan pertama penggunaan model pembelajaran adalah tujuan apa yang harus dicapai. Dalam penggunaan model pembelajaran ekspositori terdapat beberapa prinsip berikut ini, yang harus diperhatikan oleh setiap guru.

a. Berorientasi pada Tujuan
Walaupun penyampaian materi pelajaran merupakan ciri utama dalam model pembelajaran ekspositori melalui metode ceramah, namun tidak berarti proses penyampaian materi tanpa tujuan pembelajaran. Justru tujuan itulah yang harus menjadi pertimbangan utama dalam penggunaan model ini. Oleh karena itu sebelum strategi ini diterapkan terlebih dahulu guru harus merumuskan tujuan pembelajaran secara jelas dan terukur. Seperti kriteria pada umumnya, tujuan pembelajaran harus dirumuskan dalam bentuk tingkah laku yang dapat diukur atau berorientasi pada kompetensi yang harus dicapai oleh peserta didik. Hal ini sangat penting untuk dipahami, karena tujaun yang spesifik memungkinkan kita bisa mengontrol efektivitas penggunaan model pembelajaran. Memang benar, model pembelajaran ekspositori tidak mungkin dapat mengejar tujuan kemampuan berpikir tingkat tinggi, misalnya kemampuan untuk menganalisis atau mungkin mengevaluasi sesuatu, namum tidak berarti tujuan kemampuan berpikir taraf rendah tidak perlu dirumuskan. Justru tujuan itulah yang harus dijadikan ukuran dalam menggunakan model ekspositori.

\section{b. Prinsip Komunikasi}

Proses pembelajaran dapat dikatakan sebagai proses komunikasi, yang merujuk pada proses penyampaian pesan dari seseorang (sumber pesan) kepada seseorang atau sekelompok orang (penerima pesan). Pesan yang ingin disampaikan dalam hal ini adalah materi pelajaran yang diorganisir dan disusun sesuai dengan tujuan tertentu yang ingin dicapai. Dalam proses komunikasi guru berfungsi sebagai sumber pesan dan peserta didik sebagai penerima pesan. Dalam proses komunikasi, bagaimanapun sederhananya, selalu terjadi urutan pemindahan pesan (informasi) dari sumber pesan ke penerima pesan. Sistem komunikasi dikatakan efektif apabila pesan itu dapat mudah ditangkap oleh penerima pesan secara utuh. Sebaliknya sistem komunikasi dikatakan tidak efektif, apabila penerima pesan tidak dapat menangkap setiap pesan yang disampaikan. Kesulitan menangkap pesan itu dapat terjadi karena adanya berbagai gangguan (noise) yang dapat menghambat kelancaran proses komunikasi. Akibat gangguan (noise) tersebut memungkinkan penerima pesan (peserta didik) tidak memahami atau tidak dapat 
menerima sama sekali pesan yang ingin disampaikan oleh pemberi pesan (pendidik/guru). Sebagai suatu model pembelajaran yang menekankan pada proses penyampaian, maka prinsip komunikasi ini menjadi prinsip yang sangat penting untuk diperhatikan. Artinya, bagaimana upaya yang dilakukan agar setiap guru dapat menghilangkan setiap gangguan (noise) yang menghambat proses komunikasi.

\section{c. Prinsip Kesiapan}

Peserta didik dapat menerima informasi sebagai stimulus yang kita berikan, terlebih dahulu kita harus memosisikan mereka dalam keadaan siap baik secara fisik maupun psikis untuk menerima pelajaran. Kita sebagai pendidik jangan mulai menyajikan pelajaran, manakala peserta didik belum siap untuk menerimanya.

d. Prinsip Berkelanjutan

Proses pembelajaran ekspositori harus dapat mendorong peserta didik untuk mau mempelajari materi pelajaran lebih lanjut. Pembelajaran bukan hanya berlangsung pada saat itu, akan tetapi juga untuk waktu selanjutnya. Ekspositori yang berhasil apabila melalui proses penyampaian dapat membawa peserta didik pada situasi ketidakseimbangan (disequilibrium), sehingga mendorong mereka untuk mencari dan menemukan atau menambah wawasan melalui proses belajar mandiri. Keberhasilan penggunaan model ekspositori sangat tergantung pada kemampuan guru untuk bertutur atau menyampaikan materi pelajaran.

\section{Keunggulan dan Kelemahan Model Eksposotori}

Model pembelajaran ekspositori merupakan model pembelajaran yang banyak dan sering digunakan. Hal ini disebabkan model ini memiliki beberapa keunggulan, diantaranya:

1. Dengan menggunakan model pembelajaran ekspositori guru bisa mengonrol urutan dan keluasan materi pembelajaran, sehingga guru dapat mengetahui sampai sejauh mana peserta didik menguasai pelajaran yang disampaikan.

2. Model pembelajaran ekspositori dianggap sangat efektif apabila materi pelajaran yang dikuasai oleh peserta didik cukup luas, sementara waktu yang dimilki untuk belajar terbatas.

3. Melalui model pembelajaran ekspositori selain peserta didik dapat mendengar melalui penuturan tentang materi pelajaran, juga sekaligus peserta didik bisa melihat atau mengobservasi melalui pelaksanaan demonstrasi.

4. Keunggulan lain adalah model pembelajaran ekspositori ini bisa digunakan untuk jumlah peserta didik dan ukuran kelas yang besar.

Selain memilki keunggulan, model ekspositori juga memilki kelemahan, diantaranya:

1. Model pembelajaran ini hanya mungkin dapat dilakukan terhadap peserta didik yang memiliki kemampuan mendengar dan menyimak secara baik. Untuk siswa yang tidak memiliki kemampuan seperti itu perlu digunakan model lain.

2. Model pembelajaran ekspositori ini tidak mungkin dapat melayani perbedaan setiap individu baik kemampuan, pengetahuan, minat, dan bakat serta perbedaan gaya belajar.

3. Karena model ini lebih banyak diberikan melalui ceramah, maka akan sulit mengembangkan kemampuan peserta didik dalam hal kemampuan sosialisasi, hubungan interpersonal, serta kemampuan berpikir kritis.

4. Dengan model pembelajaran ini keberhasilan peserta didik sangat tergantung kepada apa yang dimiliki guru, seperti persiapan, pengetahuan, rasa percaya diri, semangat, antusiasme, motivasi, kemampuan bertutur, dan kemampuan mengelolah kelas. Tanpa semua itu sudah dipastikan proses pembelajaran tidak mungkin berhasil.

Kegiatan guru berbicara pada model ekspositori hanya dilakukan pada saat-saat terentu saja, seperti pada awal pembelajaran, menerangkan materi, memberiakan contoh soal. Kegiatan peserta didik tidak hanya mendengarkan, membuat catatan, atau memperhatikan saja, tetapi juga mengerjakan soal-soal latihan yang mungkin dalam kegiatan ini peserta didik saling bertanya. Mengerjakan 
soal latihan bersama dengan temannya, dan seorang peserta didik diminta mengerjakan dipapan tulis. Saat kegiatan peserta didik mengerjakan latihan, kegiatan guru memeriksa pekerjaan peserta didik secara individual dan menjelaskan kembali secara individual. Apabila dilihat masih banyak pekerjaan peserta didik yang belum sempurna, kegiatan tersebut diikuti penjelasan secara klasikal.

Pada umumnya guru lebih suka menggunakan model ceramah dikombinasikan dengan model tanya jawab. Model ceramah banyak dipilih karena mudah dilaksanakan dengan persiapan yang sederhana, hemat waktu, dan tenaga. Dengan satu langkah sudah bisa menjangkau semua peserta didik dan dapat dilakukan cukup di dalam kelas saja.

Baker (1992) menjelaskan bahwa setiap penyajian informasi secara lisan dapat disebut ceramah. Penyajian ceramah yang bersifat formal dan biasanya berlangsung selama 45 menit maupun yang informal yang hanya berlangsung selama 5 menit. Ceramah tidak dapat dikatakan baik atau buruk, tetapi penyampaian ceramah harus dinilai menurut tujuan penggunaannya. Oleh karena gaya komunikasi model pembelajaran lebih banyak terjadi satu arah (one-way communication), maka kesempatan untuk mengontrol pemahaman siswa akan materi pembelajaran akan sangat terbatas. Selain itu, komunikasi satu arah dapat mengakibatkan pengetahuan yang dimiliki siswa akan terbatas pada apa yang diberikan oleh guru.

\section{KESIMPULAN}

Model inkuiri adalah model pembelajaran yang menekankan kepada peserta didik untuk lebih aktif dalam pembelajaran, dimana peserta didik dapat menemukan atau meneliti masalah berdasarkan fakta untuk memperoleh data, sedangkan guru hanya sebagai fasilitator dan pembimbing peserta didik dalam belajar. Sedangkan, sebagai suatu model pembelajaran yang menekankan pada proses penyampaian, prinsip komunikasi ini menjadi prinsip yang sangat penting untuk diperhatikan dalam model pembelajaran ekspositoi. Artinya, bagaimana upaya yang dilakukan agar setiap guru dapat menghilangkan setiap gangguan (noise) yang menghambat proses komunikasi.

\section{SARAN}

Sebaiknya pendidik dapat bersikap inovatif di dalam memilih model pembelajaran yang sesuai dengan kebutuhan peserta didik dan materi pelajaran, sehingga proses pembelajaran sejarah lebih menarik dan berhasil mencapai tujuan pembelajarannya.

\section{DAFTAR PUSTAKA}

Abdul Aziz Wahab. 2009. Metode dan Modelmodel Mengajar. Bandung: Alfabeta.

A.M, Sardiman. 2006. Interaksi dan Motivasi Belajar Mengajar. Jakarta: PT Raja Grafindo Persada.

Amri, Sofan dan Iif Khoiru ahmadi. 2010. Proses Pembelajaran Inovatif dan Kreatif Dalam Kelas. Jakarta: PT. Prestasi Pustakaraya.

Baker, C. 1992. Sikap dan Bahasa. Clevedon: Masalah Multigual.

Djamarah, Sayiful Bahri. 2003. Prestasi Belajar dan Kompetensi Guru. Surabaya: Usaha Nasional.

Djamarah, Sayiful Bahri. 2003. 2008. Psikologi Belajar. Jakarta: Renika Cipta.

Hamalik, Oemar. 1993. Media Pendidikan Cetakan ke IV. Bandung: Citra Aditya.

Hamalik, Oemar. 2001. Proses Belajar Mengajar. Jakarta: Bumi Aksara.

Hamalik, Oemar. 2009. Kurikulum dan Pembelajaran. Jakarta: Bumi Aksara.

Kardi, Soeparman. 2003. Merancang Pembelajaran Menggunakan Model Inkuiri. Surabaya: UNS.

Kusmana, Suherli. 2010. Model Pembelajaran Siswa Aktif. Jakarta: PT.Penerbit Sketsa Aksara Lalitya.

Putrayasa, 2009. Model Pembelajaran Inkuiri. http://ipotes.wordpress.com. Diakses 16 Oktober 2017. Pukul 15.57 WIB).

Roestiyah. 2008. Strategi Belajar Mengajar. Jakarta: Rineka Cipta.

Sagala, Saiful. 2006. Konsep dan Makna Pembelajaran. Bandung: CV. Alfabeta.

Sanjaya, Wina. 2007. Strategi Pembelajaran Berorientasi Standar Proses Pendidikan. Jakarta: Kencana Prenada Media Group. 
Terakreditasi Peringkat 4 (No. SK: 36/E/KPT/2019)

Susanto, Ahmad. 2014. Pengembangan Pembelajaran IPS di Sekolah Dasar. Jakarta: Prenadamedia Group.

Trianto. 2007. Mendesain Model Pembelajaran Inovatif-Progresif. Surabaya: Kencana Prenada Media Group.

Yamin, Martinis. 2007. Profesionalisasi Guru \& Implementasi KTSP. Jakarta: Gaung Persada Press. 